\title{
Genetic analysis of adult-plant resistance to leaf rust in a double haploid wheat (Triticum aestivum L. em Thell) population
}

\author{
Sandra Patussi Brammer ${ }^{1}$, Maria Irene Baggio de Moraes Fernandes ${ }^{1 *}$, Amarilis Labes Barcellos ${ }^{1 * *}$ \\ and Sandra Cristina Kothe Milach" \\ ${ }^{1}$ Empresa Brasileira de Pesquisa Agropecuária, Embrapa Trigo, Passo Fundo, RS, Brazil. \\ ${ }^{2}$ Universidade Federal do Rio Grande do Sul, Faculdade de Agronomia, Departamento de Plantas \\ de Lavoura, Porto Alegre, RS, Brazil.
}

\begin{abstract}
A genetic analysis of adult plant resistance to leaf rust (Puccinia triticina) was performed in in vitro obtained double haploid progenies from a cross between the Brazilian wheat cultivar Trigo BR 35, which, under the high inoculum pressure of the southern region, has been resistant to leaf rust for more than 12 years, and the susceptible cultivar IAC 13-Lorena. Haplodiploidization via in vitro gimnogenesis was done by somatic elimination of the pollen donor genome after maize pollination of the $F_{1}$ plants. The advantages and usefulness of double haploids $(\mathrm{DH})$ for genetic analysis of complex inherited traits like durable adult-plant resistance to wheat leaf rust were evident: it was possible to analyze inheritance patterns in this cross by using only the $35 \mathrm{DH}$ homozygous segregant lines obtained by in vitro embryo culture of $F_{1}$ flowers pollinated by maize, this number being equivalent to 1,225 conventional $F_{2}$ lines because of lack of heterozygosity. After being infected with MCG and LPG races, the results indicated that Trigo BR 35 has two resistance genes. One of the genes expressed resistance only after the intermediate stage of plant development (5-6 leaves).
\end{abstract}

Key words: Puccinia triticina, resistant genes, haplodiploidization.

Received: July 17, 2003; Accepted: December 19, 2003.

\section{Introduction}

Wheat leaf rust, regularly occurring and widely distributed worldwide, is caused by Puccinia triticina Erikss. [syn. P. recondita Roberge ex Desmaz. f. sp. tritici (Anikster et al., 1997)], currently being the most important disease of wheat (Triticum aestivum $\mathrm{L}$. em Thell). Leaf rust is common in southern Brazil and under favorable environmental conditions it causes heavy losses on susceptible wheat cultivars.Its control is more economically and effectively achieved through the use of resistant cultivars (Bjarko and Line, 1988; Roelfs, 1988). Although major resistance genes have often failed after a few years of use, in many countries, the adult plant resistance of a number of South American cultivars has been durable as is the case of the cultivar Frontana (Roelfs, 1988).

Send correspondence to Sandra Patussi Brammer. Embrapa Trigo, BR 285, Caixa Postal 451, 311-3617 Passo Fundo, Rio Grande do Sul, Brazil. E-mail: sandra@ @npt.embrapa.br.

"Present address: Universidade de Passo Fundo, Instituto de Ciências Biológicas, Departamento de Biologia, Rodovia BR 285, km 171, Caixa Postal 611, 99001-970 Passo Fundo, RS, Brazil.

"Present address: OR Melhoramento de Sementes Ltda, Rua João Battisti 71, Passo Fundo, RS, Brazil.

"Present address: Pioneer Sementes, Caixa Postal 72, 99010-100 Passo Fundo, RS, Brazil. E-mail: sandra.milach@ pioneer.com.
Sing et al. (2001) report that the efforts to breed cereals for resistance to rust diseases have identified resistance expressed at seedling growth stage, effective throughout the life of the plant, and resistance that is effective on adult plants only, called adult plant resistance (APR). Genetic studies of cereals have shown that APRs are often important components of durable rust resistance. Understanding the inheritance of resistance to disease is valuable for planning crosses in breeding programs, identifying resistance genes and developing genetic markers to assist selection (Ardiel et al., 2002).

The levels of resistance of Brazilian wheat germplasm to several diseases were found to be the best ones worldwide, probably because of the higher inoculum pressure of the southern region, and have been considered extremely valuable in several countries (Roelfs, 1988). Specifically for adult plant leaf rust resistance, two complementary recessive genes have been identified in the Brazilian cultivar Toropi (Barcellos et al., 2000). It is important, however, to conduct genetic investigations of the sources of adult-plant resistance identified for breeding wheat in Southern Brazil, due to the endemic occurrence of this disease. 
Brazilian wheat cultivar Trigo BR 35, under the high inoculum pressure of the southern region, has maintained resistance for more than 12 years, and is a promising source for adult plant resistance to leaf rust. There is no information, however, about the genetics of this resistance.

This study was carried out in order to investigate inheritance patterns and the number of genes involved in the expression of durable adult-plant resistance of Trigo BR 35 , using double haploid progenies obtained via gimnogenesis by somatic elimination of the male genome, through maize pollinization followed by in vitro culture of immature embry embryos.

\section{Materials and Methods}

Pure lines of the Brazilian cultivars: Trigo BR 35, resistant, used as female parents and IAC 13-Lorena, susceptible, used as male parents, were crossed in a greenhouse at Embrapa Trigo, located in Passo Fundo, State of Rio Grande do Sul, Brazil. Double haploid progeny populations were obtained from the $F_{1}$ generation. Haplodiploidization via gimnogenesis was done through somatic elimination of the male genome, after maize pollinization followed by in vitro culture of immature embryos, as described by Laurie and Bennett (1986) and modified by Suenaga and Nakajima (1989) and Inagaki and Tahir (1990). The few completely homozygous DH recombinant first generation seeds were multiplied in order to be inoculated before genetic analysis of resistance to leaf rust.

The parental genotypes and the DH progeny lines were inoculated with single uredinial cultures of the $P$. triticina pathotypes MCG and LPG. Three-letter codes, according to the North American System of Nomenclature (Long and Kolmer, 1989), designate the ineffective host genes in the differential host set $L r 12 a 2 c 33 \mathrm{ka} 91011$ $14 a 14 b 1617182121232426$ and 30. For pathotype $\mathrm{MCG}$, the virulence combination is $L r$ ineffective genes 13 $101114 a 182326$, while that for LPG is $\operatorname{Lr} 19101114 a$ $14 b 18232426$.

The plants were inoculated at three stages of development. The experiment had two replicates of 6-8 plants each for every genotype that was maintained in a greenhouse at $22-26{ }^{\circ} \mathrm{C}$. Urediospores were suspended in lightweight mineral oil (Soltrol) and inoculated by spraying on the leaves. Plants inoculated at first fully expanded leaf stage, 7 days after planting, were placed overnight for incubation in a growth chamber at $18{ }^{\circ} \mathrm{C}$, in the dark and at $100 \%$ relative humidity, and then transferred to a greenhouse with the temperature maintained at approximately $25{ }^{\circ} \mathrm{C}$ and day length (photoperiod) of $14 \mathrm{~h}$. Scoring of disease intensity was carried out 12-14 days after inoculation. Infection types were assessed using the 0-4 scale (Roelfs and McKey, 1979; Stakman et al., 1962, described in Roelfs, 1984) and identified by the presence of chlorosis and the intensity of sporulation. Infection types 0,1 and 2 were considered indicative of host resistance, whereas infection types 3 and 4 indicated host susceptibility (high infection type). Additional infection types (+ and -) within each category were recorded as variants of the standard infection type.

When the plants reached an intermediate stage, defined by the presence of 5-6 leaves, and also at adult-plant stage, the urediospores of the same pathotypes were inoculated at the concentration of $1.5 \mathrm{mg} / 1 \mathrm{~mL}$ mineral oil (Barcellos, 1994). The conditions for incubation and rust development were as described for seedling infections. Severity was estimated based on the modified Cobb scale (Peterson et al., 1948) which analyses the percentage of leaf area infected. At the adult stage, the flag leaves of the main tiller were infected with the LPG race.

The segregation rates were subjected to $\chi^{2}$ analysis to identify the number of genes involved in the resistance.

\section{Results and Discussion}

The leaf rust reactions on plants of both parents, $F_{1}$ and segregant DH lines are presented in Table 1, Table 2 and Table 3, while Figure 1 shows several reaction patterns observed.

\section{Analysis at first leaf stage}

In relation to MCG and $\mathrm{LPG}$ races (Table 1), IAC 13-Lorena showed the expected susceptible reaction. Trigo BR 35 showed moderate susceptible reaction (3 $\left.3^{-}\right)$to $\mathrm{MCG}$ race and a moderate level of resistance to race LPG (2 $\left.3^{-}\right)$. The infection types are in accordance with the reaction conditioned by the $\operatorname{Lr} 26$ gene that was previously indicated to be in this cultivar (Rosa Filho, 1997; Zoldan, 1998).

The $\chi^{2}$ analysis of DH lines indicated that one gene (Table 3 ) is responsible for the observed difference between the parents fitting the ratio of 1 resistant: 1 susceptible plant to race MCG $(\mathrm{p}=0.50-0.30)$ as well as to race LPG $(p=0.50)$.

The observation of higher level of resistance in $F_{1}$ plants, also expressed in some double haploid lines, in comparison with the parents, may suggest either that some kind of interaction, possibly related to different backgrounds, may be involved, or minor resistance genes may occur in the susceptible cultivar IAC 13-Lorena.

\section{Analysis at intermediate stage}

At intermediate stage of plant development (5-6 leaves) the segregation observed between DH lines fits the ratio of 1 resistant: 3 susceptible plants to race MCG $(\mathrm{p}=0.30-0.20)$ and 3 resistant: 1 susceptible plant to race LPG $(\mathrm{p}=0.50-0.30)$, indicating that two genes in Trigo BR 35 may explain the resistance of this cultivar (Table 2).

\section{Analysis at flag leaf stage}

The segregation ratio indicated that two dominant genes, or one dominant plus a recessive gene, or yet two duplicated genes ( 3 resistant: 1 susceptible; $p=0.30-0.20$ ) in 
Table 1 - Response to Puccinia triticina races MCG and LPG- parents, $\mathrm{F}_{1}$ and DH lines from the cross IAC 13-Lorena and Trigo BR 35.

\begin{tabular}{|c|c|c|}
\hline & \multicolumn{2}{|c|}{ Stage of plant development } \\
\hline & \multicolumn{2}{|c|}{ Seedlings (first leaf) ${ }^{1}$} \\
\hline & $\mathrm{MCG}^{2}$ & $\mathrm{LPG}^{2}$ \\
\hline IAC13 -Lorena & $3(\mathrm{~S})$ & $3^{+}(\mathrm{S})$ \\
\hline Trigo BR 35 & $33^{-}$ & $23^{-}$ \\
\hline $\mathrm{F}_{1}$ & $;-3 ;-2$ & $; 3 ; 2$ \\
\hline \multicolumn{3}{|l|}{ DH lines } \\
\hline 4551 & $3(\mathrm{~S})$ & $2-3$ \\
\hline 4554 & 32 & $23^{-}$ \\
\hline 4555 & $3(\mathrm{~S})$ & 32 \\
\hline 4556 & $3(\mathrm{~S})$ & 2 \\
\hline 4557 & $33^{-}$ & $3^{+}(\mathrm{S})$ \\
\hline 4563 & 3 & 321 \\
\hline 4564 & $3(\mathrm{~S})$ & $43^{=}(\mathrm{S})$ \\
\hline 4565 & $33^{-}$ & $23^{=}$ \\
\hline 4566 & $3(\mathrm{~S})$ & 32 \\
\hline 4567 & $33^{-}$ & $23^{=}$ \\
\hline 4568 & $3(\mathrm{~S})$ & $33^{+}(\mathrm{S})$ \\
\hline 4569 & $3(\mathrm{~S})$ & 32 \\
\hline 4570 & $3(\mathrm{~S})$ & $4(S)$ \\
\hline 4571 & $3(\mathrm{~S})$ & $3(\mathrm{~S})$ \\
\hline 4572 & $;-3^{-}$ & $23^{=}$ \\
\hline 4573 & $;-3^{-}$ & $3(\mathrm{~S})$ \\
\hline 4574 & $2-$ & $33^{+}(\mathrm{S})$ \\
\hline 4575 & $3-;$ & $3^{+}(\mathrm{S})$ \\
\hline 4614 & $3(\mathrm{~S})$ & $3^{+}(\mathrm{S})$ \\
\hline 4615 & 32 & $3^{+}(\mathrm{S})$ \\
\hline 4616 & $3(\mathrm{~S})$ & 32 \\
\hline 4617 & $3(\mathrm{~S})$ & $3^{+} 4(\mathrm{~S})$ \\
\hline 4618 & $3(\mathrm{~S})$ & $33^{+}(\mathrm{S})$ \\
\hline 4619 & $3(\mathrm{~S})$ & $2-3$ \\
\hline 4620 & 32 & $;-3$ \\
\hline 4621 & 32 & $23^{=}$ \\
\hline 4622 & $3=$ & $323^{=}$ \\
\hline 4623 & $3(\mathrm{~S})$ & 32 \\
\hline 4650 & $3+(S)$ & $;-23^{-}$ \\
\hline 4651 & 3 & $3^{+}(\mathrm{S})$ \\
\hline 4652 & $3(\mathrm{~S})$ & 32 \\
\hline 4656 & $3(\mathrm{~S})$ & $3^{+}(\mathrm{S})$ \\
\hline 4657 & $3+(\mathrm{S})$ & $2-33^{+}$ \\
\hline 4659 & $3(\mathrm{~S})$ & $23^{-}$ \\
\hline 4660 & $3+(S)$ & $3^{+}(\mathrm{S})$ \\
\hline
\end{tabular}

${ }^{1}$ The symbols for infection types $0 ; 1$ or 2 were considered resistant and 3 to 4 , susceptible. The symbols $=-$ - and + , indicated minor and greater variation of each infection type.

${ }^{2}(S)=$ as susceptible as IAC 13-Lorena. The others expressed at least some level of resistance.
Table 2 - Response to Puccinia triticina races MCG and LPG - parents, $\mathrm{F}_{1}$ and DH lines from the cross IAC 13-Lorena and Trigo BR 35.

\begin{tabular}{|c|c|c|c|}
\hline & \multicolumn{3}{|c|}{ Stage of plant development ${ }^{1}$} \\
\hline & \multicolumn{2}{|c|}{$\begin{array}{c}\text { Intermediate } \\
\text { (5-6 leaves) }\end{array}$} & \multirow{2}{*}{$\begin{array}{c}\begin{array}{c}\text { Adult plan } \\
\text { (flag leaf) }\end{array} \\
\mathrm{LPG}^{2}\end{array}$} \\
\hline & $\mathrm{MCG}^{2}$ & $\mathrm{LPG}^{2}$ & \\
\hline IAC13 -Lorena & $16(\mathrm{~S})$ & - & $34(\mathrm{~S})$ \\
\hline Trigo BR 35 & 4 & 5 & 23 \\
\hline $\mathrm{F}_{1}$ & - & - & 7 \\
\hline \multicolumn{4}{|l|}{ DH lines } \\
\hline 4551 & $14(\mathrm{~S})$ & 4 & 5 \\
\hline 4554 & $5(\mathrm{~S})$ & $15(\mathrm{~S})$ & $50(\mathrm{~S})$ \\
\hline 4555 & 4 & 3 & $33(\mathrm{~S})$ \\
\hline 4556 & $8(S)$ & 4 & $25(\mathrm{~S})$ \\
\hline 4557 & $26(\mathrm{~S})$ & $15(\mathrm{~S})$ & - \\
\hline 4563 & $7(S)$ & $8(\mathrm{~S})$ & $35(\mathrm{~S})$ \\
\hline 4564 & $5(\mathrm{~S})$ & $25(\mathrm{~S})$ & $24(\mathrm{~S})$ \\
\hline 4565 & $10(\mathrm{~S})$ & $8(S)$ & 20 \\
\hline 4566 & $15(\mathrm{~S})$ & $10(\mathrm{~S})$ & 13 \\
\hline 4567 & $7(\mathrm{~S})$ & $7(S)$ & $27(\mathrm{~S})$ \\
\hline 4568 & $5(\mathrm{~S})$ & 4 & 21 \\
\hline 4569 & $18(\mathrm{~S})$ & $20(\mathrm{~S})$ & $30(\mathrm{~S})$ \\
\hline 4570 & $7(S)$ & $5(\mathrm{~S})$ & $43(\mathrm{~S})$ \\
\hline 4571 & 4 & 3 & 5 \\
\hline 4572 & 3 & $5(\mathrm{~S})$ & 5 \\
\hline 4573 & 4 & 3 & 10 \\
\hline 4574 & 4 & 2 & 4 \\
\hline 4575 & $10(\mathrm{~S})$ & 4 & 15 \\
\hline 4614 & $7(\mathrm{~S})$ & 3 & 5 \\
\hline 4615 & $8(S)$ & 1 & - \\
\hline 4616 & 3 & 2 & $24(\mathrm{~S})$ \\
\hline 4617 & $20(\mathrm{~S})$ & 3 & 2 \\
\hline 4618 & 3 & 3 & - \\
\hline 4619 & 2 & 2 & 19 \\
\hline 4620 & 2 & - & 2 \\
\hline 4621 & 3 & 2 & 23 \\
\hline 4622 & 4 & 2 & 5 \\
\hline 4623 & 3 & 4 & $35(\mathrm{~S})$ \\
\hline 4650 & $10(\mathrm{~S})$ & 3 & 18 \\
\hline 4651 & $12(\mathrm{~S})$ & 3 & - \\
\hline 4652 & $23(\mathrm{~S})$ & 2 & $24(\mathrm{~S})$ \\
\hline 4656 & $13(\mathrm{~S})$ & 4 & 23 \\
\hline 4657 & $23(\mathrm{~S})$ & 1 & 10 \\
\hline 4659 & $6(S)$ & 1 & 3 \\
\hline 4660 & $6(S)$ & $5(\mathrm{~S})$ & - \\
\hline
\end{tabular}

${ }^{1}$ At intermediate and adult plant stages, the mean severity in plants of each genotype was estimated as the percentage of leaf area infected.

${ }^{2}(S)=$ more susceptible than the reaction presented by Trigo BR 35, $(-)=$ not available. 
Table 3 - Segregation ratios of doubled haploids lines to isolates MCG and LPG of Puccinia triticina.

\begin{tabular}{lcccccc}
\hline \multirow{2}{*}{ Pathotype } & DH lines number & Stage of plant development & & \multicolumn{2}{c}{ Segregation ratio resistant: susceptible $^{2}$} & \multirow{2}{*}{$\chi^{2}$ Yates correction $^{*}$ Probability $^{3}$} \\
\cline { 3 - 5 } & & & N. lines & Ratio & & \\
\hline MCG & 35 & Seedling & $14: 21$ & $1: 1$ & 1.03 & $0.50-0.30$ \\
MCG & 35 & Intermediate & $12: 23$ & $1: 3$ & 1.15 & $0.30-0.20$ \\
LPG & 35 & Seedling & $20: 15$ & $1: 1$ & 0.46 & 0.50 \\
LPG & 34 & Intermediate & $23: 11$ & $3: 1$ & 0.63 & $0.50-0.30$ \\
LPG & 30 & Adult & $19: 11$ & $3: 1$ & 1.60 & $0.30-0.20$ \\
\hline
\end{tabular}

${ }^{1}$ The inoculations were made at first leaf, 5-6 leaves and flag leaves.

${ }^{2}$ Resistance includes all plants as resistant as Trigo BR 35.

${ }^{3}$ Probability values greater than 0.05 indicate a non significant value of $\chi^{2}$.

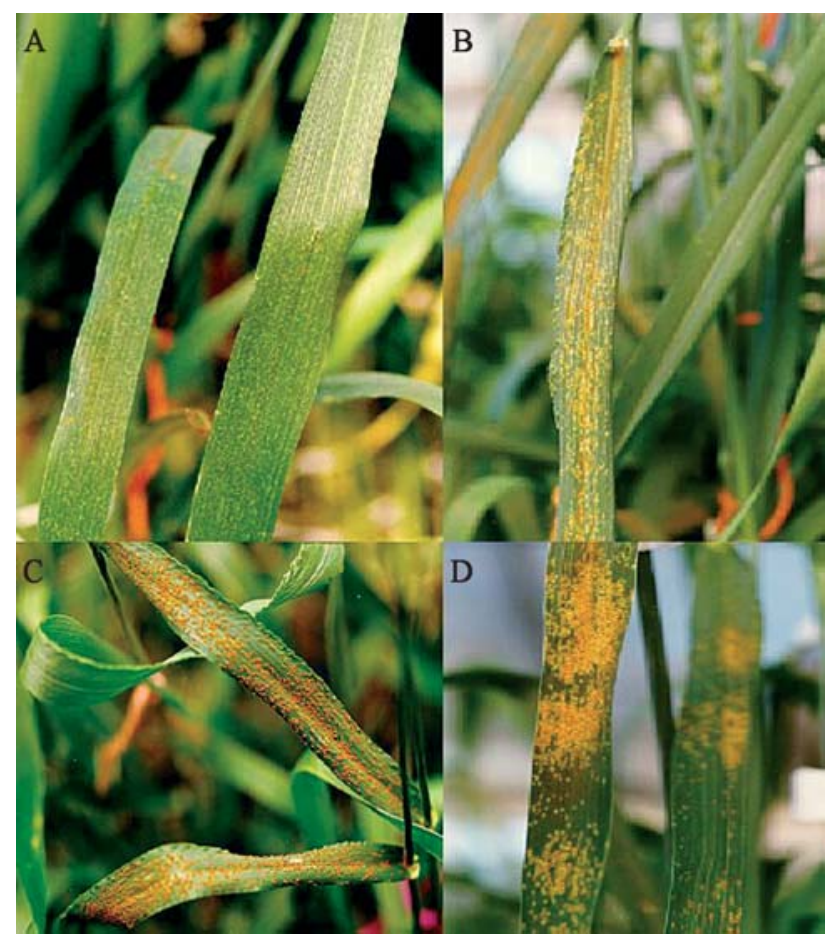

Figure 1 - Leaf rust reaction on flag leaves of double haploid plants. A, B and D - different levels of resistance; C - susceptibility.

Trigo BR 35 are responsible for the resistance to the LPG race, based on the flag leave reactions of the DH lines (Table 2).

The hypothesis of two genes agrees with that obtained at an intermediate growth stage (5-6 leaves). However, recessivity was observed for MCG race and dominance for LPG race at intermediate stage. This change of dominance has been reported previously. Genetic backgrounds of the host and the pathogen as well as environmental conditions may explain this change, temperature being the most frequently reported factor involved (Loegering, 1984; McIntosh and Dyck, 1975; Pretorius et al., 1988; Barcellos, 1994).

Leaf tip necrosis is a morphological marker for the Lr34 gene, which was observed by Sousa and Barcellos
(1999) in Trigo BR 35. In this experiment, segregation analysis of only $35 \mathrm{DH}$ lines, that correspond to 1,225 plants in the conventional $\mathrm{F}_{2}$ population (Demarly, 1977), indicated that Trigo BR 35 expressed two genes for resistance, possibly $L r 34$ for adult plant resistance and $L r 26$, a seedling resistance gene to some races that is expressed in all plant cycle. The possibility of another gene not yet described cannot be completely excluded.

Since there is no heterozygosity, the square root of the conventional $\mathrm{F}_{2}$ population size is enough for obtaining the same probability of occurrence of any given genotype (Demarly, 1977). The 'immortal' nature of the DH lines facilitated easy detection of the genes under the different pathotype $\mathrm{x}$ temperature combinations and also rapid and efficient identification of the genes for resistance. In contrast, material which is still segregating does not allow a definite judgement (Steffenson et al.,1995).

Although designated as a gene for adult-plant resistance, Lr34 has been detected at the seedling growth stage, conferring infection type 3 to 3 ; to 3 or 2 to 3 (several authors cited in McIntosh et al., 1995). The mechanism for durable resistance to leaf rust is poorly understood, but durability appears to be enhanced when genes are combined (Raupp et al., 2000). For example, German and Kolmer (1992) described the enhancing effects of Lr34 on the seedling and adult-plant response of some leaf rust resistance genes, including $L r 26$.

According to Dyck et al. (1966) and Roelfs (1988) most resistance genes for which the inheritance has been studied are effective in the seedling stage. These genes are much easier to evaluate, require less expense and labor to be studied and therefore are much more frequently selected for genetic research than genes for adult plant resistance. Nevertheless, adult plant resistance has frequently been associated with durable resistance.

The indication that the durable resistance of Trigo BR 35 is due to a few genes is of practical importance for wheat breeding, since this kind of resistance has frequently been considered of complex inheritance. Since haplodiploidization provides an opportunity to produce, in only one generation, completely homozygous gene combinations from 
segregating material and the lines, because heterozygosity is removed as a source of variation, can be propagated without further segregation, repeat testing can be carried out to confirm disease reaction ( $\mathrm{Lu}$ et al., 1997; Knox et al., 1998). The same population used here, including the parental genotypes and $\mathrm{DH}$ progenies, may be used in the future for genetic analysis using other races than MCG and LPG, with different virulence genes, helping to clarify the role of other genes related to the durable adult-plant resistance of Trigo BR 35.

\section{Acknowledgements}

This work was supported by grants and fellowships from the Empresa Brasileira de Pesquisa Agropecuária (Embrapa) Pronex 97 program and Conselho Nacional de Desenvolvimento Científico e Tecnológico (CNPq). The authors are thankful to Dr. Cantídio Nicolau Alves de Sousa and Rainoldo Kochhann for critical review.

\section{References}

Anikster Y, Bushnell WR, Eilam T, Manisterski J and Roelfs AP (1997) Puccinia recondita causing leaf rust on cultivated wheats, wild wheats, and rye. Can J Bot 75:2082-2096.

Ardiel GS, Grewal TS, Deberdt P, Rossnagel BG and Scoles GJ (2002) Inheritance of resistance to covered smut in barley and development of a tightly linked SCAR marker. Theor Appl Genet 104:457-464.

Barcellos AL (1994) Genética da resistência de planta adulta à ferrugem da folha na cultivar brasileira de trigo Toropi (Triticum aestivum L. em. Thell). PhD Thesis, Universidade Federal do Rio Grande do Sul, Porto Alegre.

Barcellos AL, Roelfs AP and Moraes-Fernandes MIB (2000) Inheritance of adult plant leaf rust resistance in the Brazilian wheat cultivar Toropi. Plant Dis 84:90-93.

Bjarko ME and Line RF (1988) Quantitative determination of the gene action of leaf rust resistance in four cultivars of wheat, Triticum aestivum. Phytopathology 78:451-456.

Demarly Y (1977) Génétique et amélioration des plantes. Collection Sciences Agronomiques, Paris, 287 pp.

Dyck PL, Samborsky DJ and Anderson LG (1966) Inheritance of adult plant leaf rust resistance derived from the common wheat varieties Exchange and Frontana. Can J Genet Cytol 8:665-671.

German SE and Kolmer JA (1992) Effect of gene Lr34 in the enhancement of resistance to leaf rust of wheat. Theor Appl Genet 84:97-105.

Inagaki M and Tahir M (1990) Comparison of haploid production frequencies in wheat varieties crossed with Hordeum bulbosum L. and maize. Jpn J Breed 40:209-216.

Knox RE, Fernandez MR, Brule-Babel AL and DePauw RM (1998) Inheritance of common bunt resistance in androgenetically derived doubled-haploid and random inbred populations of wheat. Crop Sci 38:1119-1124.

Laurie DA and Bennet MD (1986) Wheat x maize hybridization. Can J Genet Cytol 28:313-316.

Loegering WQ (1984) Genetics of the pathogen-host association. In: Bushnell WR and Roelfs AP (eds) The Cereal Rusts: Ori- gins, Specificity, Structure and Physiology. Academic Press, Orlando, pp 165-192.

Long DL and Kolmer JA (1989) A North American System of Nomenclature for Puccinia recondita f. sp. tritici. Phytophatology 79:525-529.

Lu C, Shen L, Tan Z, Xu Y, He P, Chen Y and Zhu L (1997) Comparative mapping of QTLs for agronomic traits of rice across environments by using a doubled-haploid population. Theor Appl Genet 94:145-150.

McIntosh RA and Dyck PL (1975) Cytogenetical studies in wheat. VII Gene Lr23 for reaction to Puccinia recondita in Gabo and related cultivars. Aust J Sci 28:201-211.

McIntosh RA, Wellings CR and Park RF (1995) Wheat rusts: An atlas of resistance genes. Kluwer, Dordrecht, 200 pp.

Peterson RF, Campbell AB and Hannah, AE (1948) A diagrammatic scale for rust intensity on leaves and stems of cereals. Can J Res 26:496-500.

Pretorius ZA, Rijkenberg FHJ and Wilcoxson RD (1988) Temperature-specific seedling resistance and adult-plant resistance to Puccinia recondita $\mathrm{f}$. $\mathrm{sp}$. tritici in the wheat cultivar Glenlea. Plant Dis 72:439-442.

Raupp WJ, Sukhwinder-Singh, Brown-GuediraGL and Gill BS (2000) Cytogenetic and molecular mapping of the leaf rust resistance gene $L r 39$ in wheat. Theor Appl Genet 102:347352.

Roelfs AP and McKey J (1979) Low infection types produced by Puccinia graminis f. sp. tritici and wheat lines with designated genes for resistance. Phytopathology 69:722-730.

Roelfs AP (1984) Race specificity and methods of study. In: Bushnell WR and Roelfs AP (eds) The Cereal Rusts: Origins, Specificity, Structure and Physiology. Academic Press, Orlando, pp 131-164.

Roelfs AP (1988) Resistance to leaf rust and stem rust of wheat. In: Simmonds NW and Rajaram S (eds) Breeding Strategies for Resistance to the Rusts of Wheat. CIMMYT, México, pp 10-22.

Rosa Filho O (1997) Effect of the six glutenin loci on selected based quality traits in wheat. PhD Thesis. Oregon State University, Corvallis.

Sousa CNA de and Barcellos AL (1999) Avaliação da necrose da ponta da folha associada ao gene Lr34, em cultivares de trigo. Anais Reunião Nacional de Pesquisa de Trigo, Passo Fundo, Brazil.

Sing D, Park RF and McIntosh RA (2001) Inheritance of seedling and adult plant resistance to leaf rust of selected Australian spring and English winter wheat varieties. Plant Breed 120:503-507.

Steffenson BJ, Rossnagel Y, Jin BG, Rasmussen JB and Kao K (1995) Genetics of multiple disease resistance in a double-haploid population of barley. Plant Breed 114:50-54.

Suenaga K and Nakajima K (1989) Efficient production of haploid wheat (Triticum aestivum L.) through crosses between Japanese wheat and maize (Zea mays) Plant Cell Rep 8:263-266.

Zoldan SM (1998) Identificação de genes de resistência à ferrugem da folha em cultivares brasileiras de trigo (Triticum aestivum L.). MSc Thesis, Universidade de Passo Fundo, Passo Fundo.

Associate Editor: José Francisco Ferraz de Toledo 